\title{
OPTIMIZATION DESIGN FOR ROADHEADER CUTTING HEAD BY ORTHOGONAL EXPERIMENT AND FINITE ELEMENT ANALYSIS
}

\author{
Xueyi Li, Yonggang Lv, Shucai Xu, Qingliang Zeng, Binbing Huang
}

Original scientific paper

Optimization design for roadheader cutting head is investigated in this paper. For this purpose, the rotation velocity, the swing velocity, the cutting angles of picks, and the inclination angles of picks are chosen as the variable for the optimization, and the mean value of resultant force and variation coefficient of cutting load are chosen as optimization objective. The effects of these parameters on evaluation indexes are studied by orthogonal experiment and finite element analysis. The change trend of the evaluation indexes with the experimental factors is also carried out. Compared with the original design, the two evaluation indexes decreased by $18,3 \%$ and $5,5 \%$ after optimization design separately, which improves the cutting performance of roadheader cutting head efficiently.

Keywords: cutting angle of picks; cutting head; finite element analysis; inclination angle of picks; orthogonal experiment; rotation velocity; swing velocity

Optimizacija konstrukcije rezne glave stroja za bušenje primjenom ortogonalnog eksperimenta i analize konačnih elemenata

Izvorni znanstveni članak

U radu se istražuje optimizacija konstrukcije rezne glave stroja za bušenje. U tu su svrhu kao varijable optimizacije izabrani brzina rotacije, brzina oscilacije, rezni kutovi pijuka i kutovi nagiba pijuka, a kao ciljevi optimizacije izabrani su srednja vrijednost rezultirajuće sile i koeficijent varijacije reznog opterećenja. Učinci ovih parametara na indekse evaluacije analiziraju se ortogonalnim eksperimentom i analizom konačnih elemenata. Također je provedena analiza promjene trenda indeksa evaluacije s promjenama eksperimentalnih čimbenika. U usporedbi s originalnim projektom, dva indeksa evaluacije smanjila su se za 18,3 \% i 5,5 \% nakon optimizacije, čime je značajno poboljšana rezna performansa rezne glave stroja za bušenje.

Ključne riječi: rezni kut pijuka; rezna glava; analiza konačnih elemenata; nagibni kut pijuka; ortogonalni eksperiment; brzina rotacije; brzina oscilacije

\section{Introduction}

As the laneway excavation equipment, roadheader plays an important role in the constructions of tunnels or development and production in underground mines. Cutting head is the operating mechanism directly taking part in cutting, which consumes most of the machine's power in the process of coal and rock cutting [1]. There are various factors influencing the performance of roadheader cutting head during the cutting process, which mainly include the structural parameters itself, the kinematics parameters of the machine, the physical and mechanical properties of coal and rock, and so on. Reasonable cutting parameters can reduce the vibration of the whole machine and improve cutting efficiency greatly.

In order to study the effects of various factors on the performance of roadheader cutting head and optimize them efficiently, many scholars have done a lot of research. Hekimoglu et al. [2] studied the angle of wrap which affects the cutting performance of drum shearers and continuous miners. Bilgin et al. [3] researched the effects of some geological and geotechnical factors on the performance of a roadheader in an inclined tunnel. Khair [4] examined the fragmentation process of rock/coal by cutting head and studied the effect of bit geometry on fragmentation. Sun et al. [5] studied the influence of cutting interactions on cutting force of a pick. Zhang et al. [6] compared cutting performance of longitudinal cutting heads with various numbers of helical lines. Guo et al. [7] studied the influence of the rotation velocity and the horizontal swinging velocity on cutting head by theoretical analysis and computer simulation. Zhang $[8,9]$ put forward an analysis method of translational speed to rotate speed for cutting head by pick trajectory. Rostami et al. [10] discussed the effects of parameters related to roadheader performance on the production and advance rate, and optimized these parameters. Zhang et al. [11 $\div 13]$ researched multi-objective optimization for cutting head of roadheader based on genetic algorithm or ant colony algorithm. Zhang et al. $[14 \div 16]$ studied optimized design of kinematics parameters and multi-objective optimization design for cutting head of roadheader. Peng et al. [17] also studied optimization to the motion parameter of the cutting head of the transverse tunneler and analyzed the load by simulation. Sha et al. [18] chose cutting head drilling rate as the aim of optimal design, cutting head diameter, cutting first hand tap corner, rise angle of the helical blade, and some other design variables were optimized. However, people seldom consider the effects of interactions of different factors on the performance of cutting head, and the influence rule of various factors have not been researched systematically.

With the development of simulation technology, many people have tried to study the coal and rock cutting with numerical simulation using discrete element method or finite element method $[19 \div 23]$. Orthogonal experiment is a design method to study multiple factors level which is often used for performance optimization of operating parameters of equipment [24], and many researchers have done optimization with this method and numerical

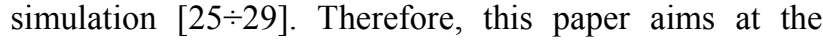
optimization design for roadheader cutting head, for this purpose, the rotation velocity, the swing velocity, the cutting angle of picks, and the inclination angle of picks are chosen as the variable for the optimization under the overall dimensions and pick arrangements of cutting head remain unchanged, and the mean value of resultant force and variation coefficient of cutting load are chosen as optimization objective, the effects of these parameters on evaluation indexes and the optimization design for cutting 
head are investigated by finite element analysis and orthogonal experiment.

\section{Evaluation Index for the optimization design}

Cutting load is a main factor directly reflecting work condition of the machine and the cutting performance. In this paper, we take the mean value of resultant force and variation coefficient of cutting load as evaluation index for the optimization design, which influence the fatigue and fluctuation of cutting head. Many scholars have studied the methods to calculate the cutting load of cutting head [30, 31]; however, no accepted and unified calculation method has been put forward.

\subsection{Theoretical calculation method}

Theoretically, we can use the calculation method given by the former Soviet Union scholar to calculate the cutting load of cutting head as follows [32]:

For conical picks:

$$
\left\{\begin{array}{l}
P_{z i}=\sigma\left[k_{1} k_{2} k_{3}(0,25+0,18 t h)+0,1 S\right] \\
P_{y i}=P_{z i}(0,15+0,00056 \sigma) \frac{2,5}{h^{0,4}} \\
P_{x i}=P_{z i}\left(\frac{C_{1}}{C_{2}+h}+C_{3}\right) \frac{h}{t}
\end{array},\right.
$$

where $P_{z i}, P_{y i}$ and $P_{x i}$ are cutting resistance, tractive resistance, and side resistance on cutting pick $(\mathrm{N}) ; \sigma$ is the contact strength of the coal and rock (MPa); $k_{1}$ is the coefficient of type of cutting picks, for conical picks $k_{1}=$ 1,$5 ; k_{2}$ is the coefficient of cutting pick geometrical shape; $k_{3}$ is the coefficient of chamfering of cutting pick; $t$ is the average transversal spacing $(\mathrm{mm}) ; h$ is the average cutting thickness $(\mathrm{mm}) ; S$ is the projected area of cutting pick after blade surface in the traction direction $\left(\mathrm{mm}^{2}\right) ; C_{1}, C_{2}$ and $C_{3}$ are influence coefficients of breakout patterns.

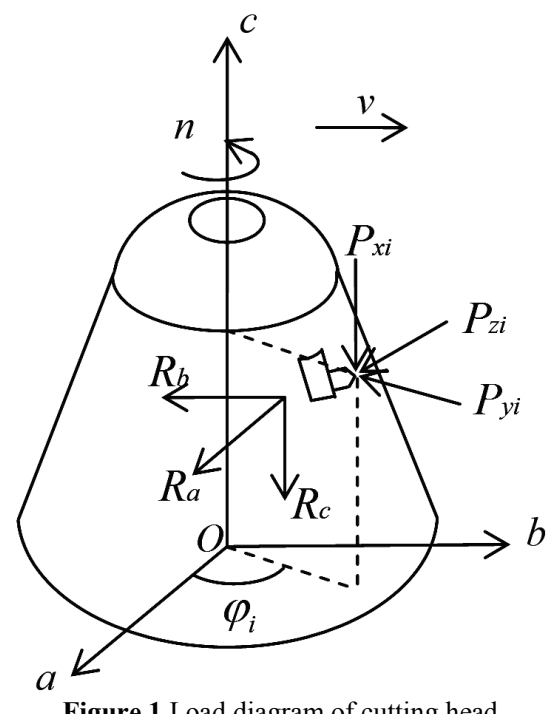

For whole cutting head:

$$
\begin{aligned}
& \left\{\begin{array}{l}
R_{a}=\sum_{i=1}^{k}\left(P_{z i} \cos \varphi_{i}+P_{y i} \sin \varphi_{i}\right) \\
R_{b}=\sum_{i=1}^{k}\left(P_{z i} \sin \varphi_{i}-P_{y i} \cos \varphi_{i}\right), \\
R_{c}=\sum_{i=1}^{k} P_{x i}
\end{array}\right. \\
& R=R_{a}+R_{b}+R_{c},
\end{aligned}
$$

where $R_{a}, R_{b}, R_{c}$ and $R$ are traversing force, vertical force, axial force, and resultant force on cutting head $(\mathrm{N}) ; k$ is the number of picks which participate in cutting at this moment, $\varphi_{i}$ is the position angle of a single cutting pick $\left(^{\circ}\right)$. The load diagram of cutting head is shown in Fig. 1, where $n$ is the rotation velocity of the cutting head $(\mathrm{r} / \mathrm{min}) ; v$ is the swing velocity of cutting head $(\mathrm{m} / \mathrm{min})$.

However, the loads on cutting head are dynamic and nonlinear due to the nonlinear contact, nonlinear materials, and complex arrangements of cutting picks. Therefore, the theoretical calculation method cannot describe the complex process of coal and rock cutting accurately and comprehensively. So we will try to calculate the cutting load by finite element simulation method in this paper.

\subsection{Finite element simulation method}

In order to get the cutting load during the roadheader cutting process, we take finite element simulation by using ANSYS/LS-DYNA. The simulation process mainly includes the establishment of 3D (three dimensional) model, selecting element type, defining the material parameter, finite element modeling, defining the contact and constraints, loading and solving.

The structural parameters of cutting head are shown in Tab. 1. The original parameter for the four variables are: the rotation velocity with $48 \mathrm{r} / \mathrm{min}$, the swing velocity with $1,5 \mathrm{~m} / \mathrm{min}$, the cutting angle of picks with $48^{\circ}$, and the inclination angle of picks with $9^{\circ}$.

Table 1 Structure parameter of cutting head

\begin{tabular}{|c|c|c|c|c|c|}
\hline $\begin{array}{c}\text { Overall } \\
\text { length } \\
(\mathrm{mm})\end{array}$ & $\begin{array}{c}\text { Cylindrical } \\
\text { diameter } \\
(\mathrm{mm})\end{array}$ & $\begin{array}{c}\text { Cylindrical } \\
\text { length } \\
(\mathrm{mm})\end{array}$ & $\begin{array}{c}\text { Spherical } \\
\text { radius } \\
(\mathrm{mm})\end{array}$ & $\begin{array}{c}\text { Number } \\
\text { of spiral } \\
\text { lines }\end{array}$ & $\begin{array}{c}\text { Number } \\
\text { of picks }\end{array}$ \\
\hline 900 & $\varnothing 850$ & 140 & $R 400$ & 3 & 30 \\
\hline
\end{tabular}

Table 2 Material parameters

\begin{tabular}{|l|c|c|}
\hline \multicolumn{1}{|c|}{ Parameters } & Coal-rock & Cutting head \\
\hline Mass density $\left(\mathrm{g} / \mathrm{mm}^{2}\right)$ & $1,5 \mathrm{e}-3$ & $7,8 \mathrm{e}-3$ \\
\hline Poisson's ratio & 0,3 & 0,3 \\
\hline Elastic shear modulus $(\mathrm{MPa})$ & 1400 & $2,7 \mathrm{e}+5$ \\
\hline Failure surface shape parameter & 1 & \\
\hline Angle of friction $(\mathrm{rad})$ & 0,45 & \\
\hline Cohesion value $(\mathrm{MPa})$ & 0,766 & \\
\hline Dilation angle $\left({ }^{\circ}\right)$ & 0 & \\
\hline
\end{tabular}

In this analysis, we select element type with SOLID 164 for all the models and define material of cutting head with *MAT RIGID and coal and rock with *MAT_DRUCKER_PRAGER and the parameters of the materials are shown in Tab. 2, set the contact type between them for eroding surface to surface (ESTS), 
apply the different rotation velocity and swing velocity to the cutting head, the load curves on the cutting head of original parameter is shown in Fig. 2 and Fig. 3, add nonreflecting boundary conditions to surfaces of coal and rock without cutting in the simulation system and limit the degrees of freedom of other directions. Add output contact surface reaction keyword "RCFORC" for the force output of cutting head with 100 steps [1]. The finite element model for load calculation of cutting process is shown in Fig. 4 and numbers of elements are 234435 and nodes are 244293 . With the finite element analysis of the cutting process, the time history curve of the resultant force on cutting head can be obtained from the simulation, which is shown in Fig. 5.

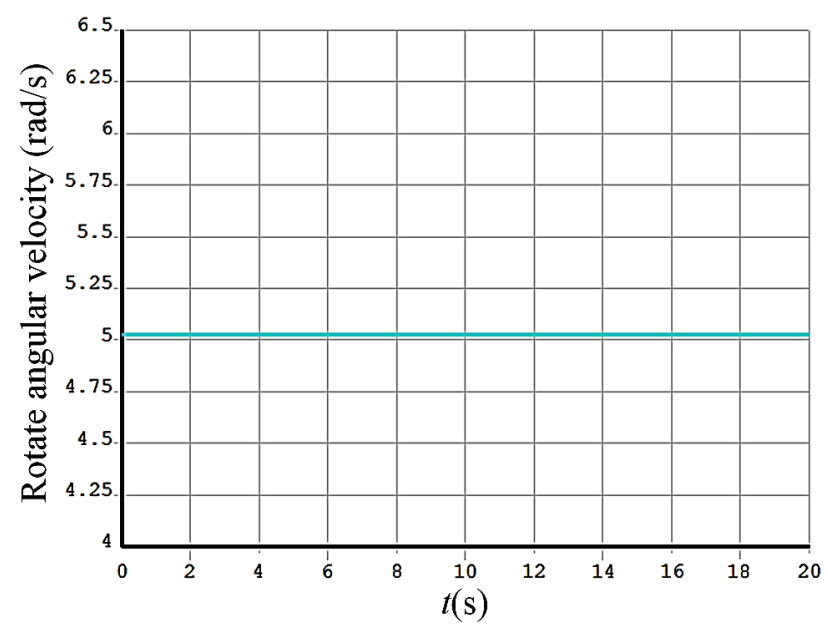

Figure 2 The rotate angular velocity for cutting process

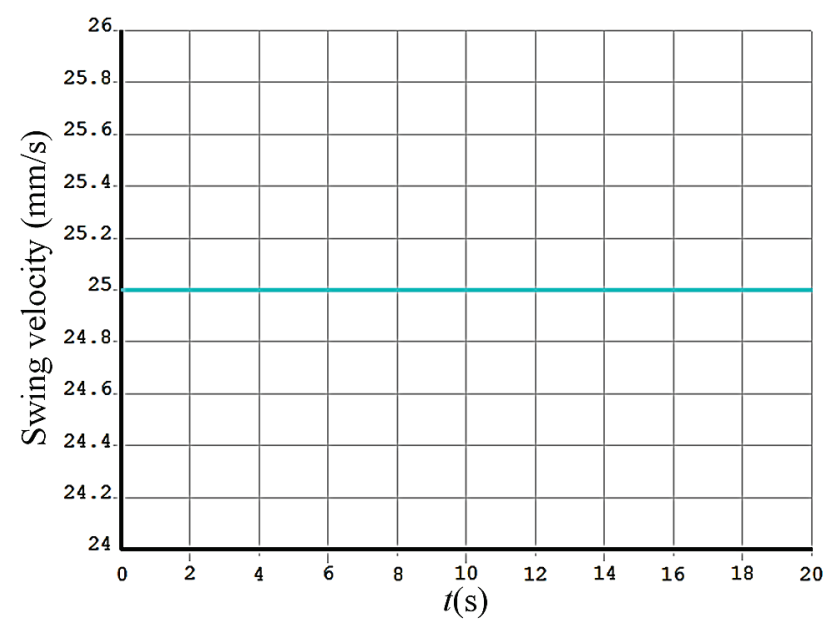

Figure 3 The swing velocity for cutting process

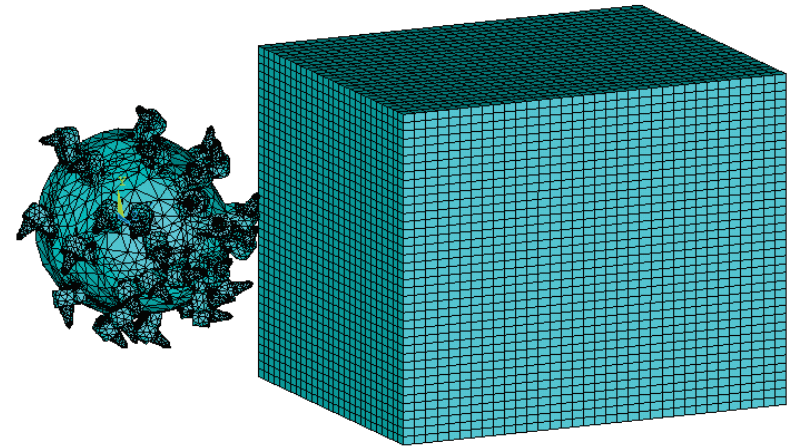

Figure 4 The finite element model for cutting process

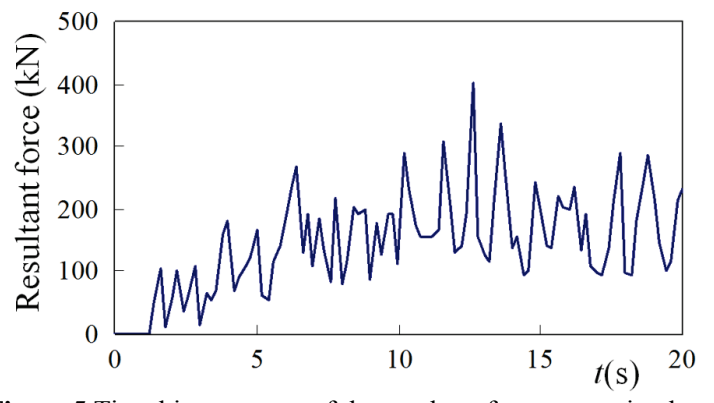

Figure 5 Time history curve of the resultant force on cutting head

The variation coefficient of cutting load can reflect the load fluctuation of cutting head; we can calculate the variation coefficient $\gamma_{\mathrm{R}}$ by the following equation:

$\gamma_{\mathrm{R}}=\frac{\sigma_{\mathrm{R}}}{E_{\mathrm{R}}}$,

where $\sigma_{\mathrm{R}}$ is the standard deviation of resultant force on cutting head, $E_{\mathrm{R}}$ is the mean value of resultant force. They can be calculated by the following equation:

$$
\begin{aligned}
& \sigma_{\mathrm{R}}=\sqrt{\frac{1}{n_{\mathrm{t}}} \sum_{i=1}^{n_{\mathrm{t}}}\left(R_{i}-E_{\mathrm{R}}\right)^{2}}, \\
& E_{\mathrm{R}}=\frac{1}{n_{\mathrm{t}}} \sum_{i=1}^{n_{\mathrm{t}}} R_{i},
\end{aligned}
$$

where $R_{i}$ is the resultant force on cutting head at the moment $i, n_{\mathrm{t}}$ is the number of the moment for the simulation.

\section{Influence of single factor on evaluation index 3.1 Analysis of the rotation velocity of cutting head}

In order to be able to realize the crushing of coal and rock, the value of cutting force on cutting head should be larger than the value of cutting resistance; the rotation velocity of cutting head should satisfy the following relations under the certain cutting power by theoretical analysis [32]:

$n \leq \frac{38200 P}{N \times D \times F}$

where $P$ is the cutting power $(\mathrm{kW}) ; N$ is the number of cutting picks; $D$ is the mean diameter of cutting head (m); $F$ is mean cutting resistance on single cutting pick $(\mathrm{N})$.

The value of rotation velocity also has influence on roadheader cutting load, in order to study the change law affected by this factor, we set rotation velocity as $24 \mathrm{r} / \mathrm{min}$, $36 \mathrm{r} / \mathrm{min}, 48 \mathrm{r} / \mathrm{min}, 60 \mathrm{r} / \mathrm{min}$, and $72 \mathrm{r} / \mathrm{min}$ for the experiment under the swing velocity with $1,5 \mathrm{~m} / \mathrm{min}$, the cutting angle of picks with $48^{\circ}$, and the inclination angle of picks with $8^{\circ}$. The mean value of resultant force and variation coefficient of cutting load under different rotation velocity are shown in Fig. 6.

From the relation curve we can see that the mean value of resultant force decreases along with the increase 
of rotation velocity and the variation coefficient of cutting load increases slightly along with the increase of rotation velocity. The results reflect the increased vibration of roadheader cutting head with the larger rotation velocity, and the lower rotation velocity of cutting head can lead to larger value of resultant force. Therefore, the reasonable rotation velocity of cutting head should be between 36 $\mathrm{r} / \mathrm{min}$ to $60 \mathrm{r} / \mathrm{min}$ according to experiment.

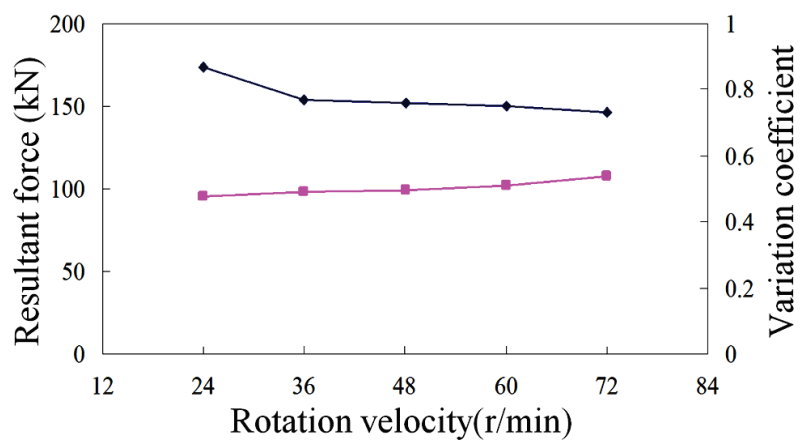

Figure 6 Mean value of resultant force and variation coefficient of cutting load under different rotation velocity

\subsection{Analysis of the swing velocity of cutting head}

The value of swing velocity of cutting head determines the life of picks and the cutting performance, and also has an important impact on the efficiency of production. According to theoretical Eq. (8), the theoretical productivity of roadheader has direct ratio to the value of swing velocity. Therefore, it is advantageous to increase the value of swing velocity to improve production capacity.

$Q=60 \lambda S_{\mathrm{a}} v$,

where $Q$ is the theoretical productivity $\left(\mathrm{m}^{3} / \mathrm{h}\right) ; \lambda$ is the coefficient of volumetric expansion of coal and rock; $S_{\mathrm{a}}$ is the axial cross-sectional area of cutting head $\left(\mathrm{m}^{2}\right) ; v$ is the swing velocity of cutting head $(\mathrm{m} / \mathrm{min})$.

In order to research the influences of swing velocity on evaluation indexes, establish different models with different swing velocity $(0,9 \mathrm{~m} / \mathrm{min}, 1,2 \mathrm{~m} / \mathrm{min}, 1,5$ $\mathrm{m} / \mathrm{min}, 1,8 \mathrm{~m} / \mathrm{min}$, and $2,1 \mathrm{~m} / \mathrm{min}$ ) under constant rotation velocity $(36 \mathrm{r} / \mathrm{min})$, cutting angle of picks $\left(48^{\circ}\right)$ and inclination angle of picks $\left(9^{\circ}\right)$, and get the relation curves of evaluation index and swing velocity which is shown in Fig. 7.

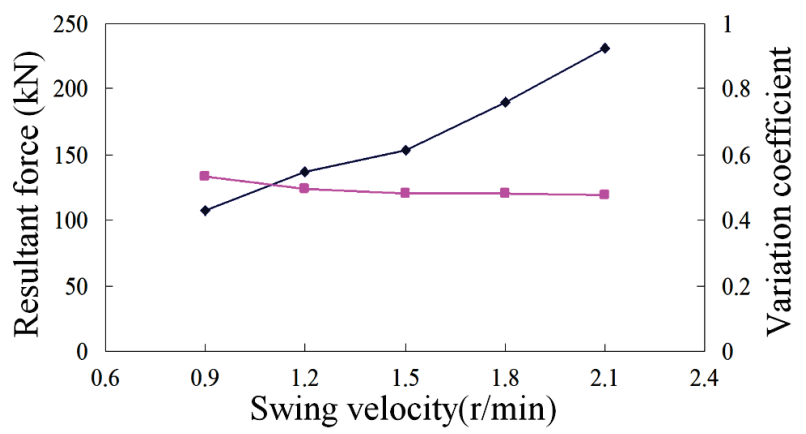

Figure 7 Mean value of resultant force and variation coefficient of cutting load under different swing velocity
We can see clearly from the relation curve that the mean value of resultant force increases rapidly along with the increase of swing velocity and the variation coefficient of cutting load decreases along with the increase of swing velocity. We can think that the thickness of the cutting increases along with the increase of swing velocity, which results in the increase of the mean value of resultant force. But, we cannot consider that the swing velocity is the lower the better, because the low swing velocity will seriously affect productivity, therefore, all the influencing factors must be taken integrated into consideration to determine the range of reasonable swing velocity and the best choice is between $1.2 \mathrm{~m} / \mathrm{min}$ and $1.8 \mathrm{~m} / \mathrm{min}$ for this type of cutting head.

\subsection{Analysis of the cutting angle of picks}

Cutting angle is the angle between the axis of the pick and the tangent of motion trajectory of the pick's tip (shown in Fig. 8), which has great influence on cutting load.

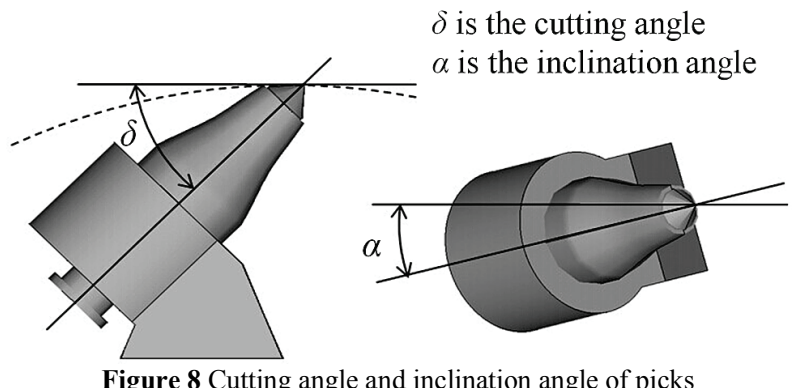

In order to study the influences of cutting angle of picks on evaluation indexes, establish the finite element analysis model of cutting process with the cutting angle for $45^{\circ}, 46^{\circ}, 47^{\circ}, 48^{\circ}$, and $49^{\circ}$ under constant rotation velocity (36 r/min), swing velocity $(1,5 \mathrm{~m} / \mathrm{min})$ and inclination angle of picks $\left(9^{\circ}\right)$, simulate the cutting process with different models and get the evaluation indexes under different cutting angle of picks as shown in Fig. 9.

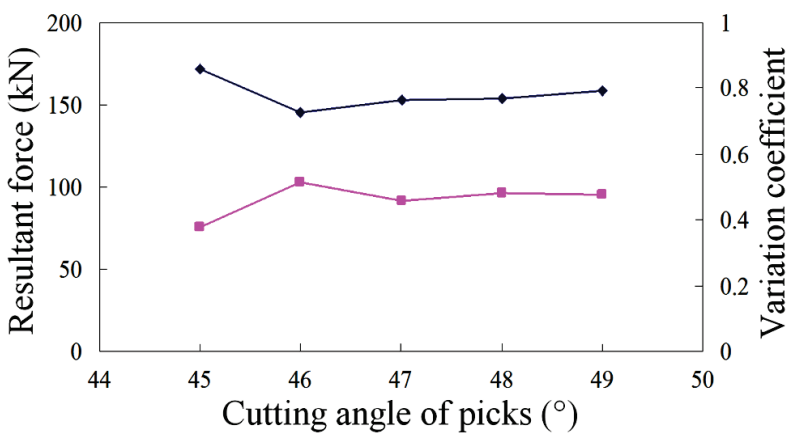

Figure 9 Mean value of resultant force and variation coefficient of cutting load under different cutting angle of picks

According to the curves of mean value of resultant force and variation coefficient of cutting load under different cutting angle of picks shown in Fig. 9 above, when the cutting angle is $45^{\circ}$, the mean value of resultant force is large and the variation coefficient of cutting load is small, the evaluation indexes show opposite trend when 
the cutting angle is $46^{\circ}$. So, the reasonable cutting angle of picks is between $47^{\circ}$ and $49^{\circ}$.

\subsection{Analysis of the Inclination angle of picks}

Inclination angle of picks reflect the horizontal angle (view from the top of the pick) between the axis of the pick and the motion direction of pick's tip [33], which is shown in Fig. 8.

Reasonable inclination angle of picks can reduce the wear of cutting picks and extend service life of cutting head. In order to get the reasonable inclination angle of picks for this cutting head, establish different models with different inclination angle of picks $\left(5^{\circ}, 6^{\circ}, 7^{\circ}, 8^{\circ}\right.$, and $\left.9^{\circ}\right)$ under constant rotation velocity $(36 \mathrm{r} / \mathrm{min})$, swing velocity $(1,5 \mathrm{~m} / \mathrm{min})$, and cutting angle of picks $\left(48^{\circ}\right)$, and take the finite element analysis of different cutting process. The mean value of resultant force and variation coefficient of cutting load under different inclination angle of picks are shown in Fig. 10.

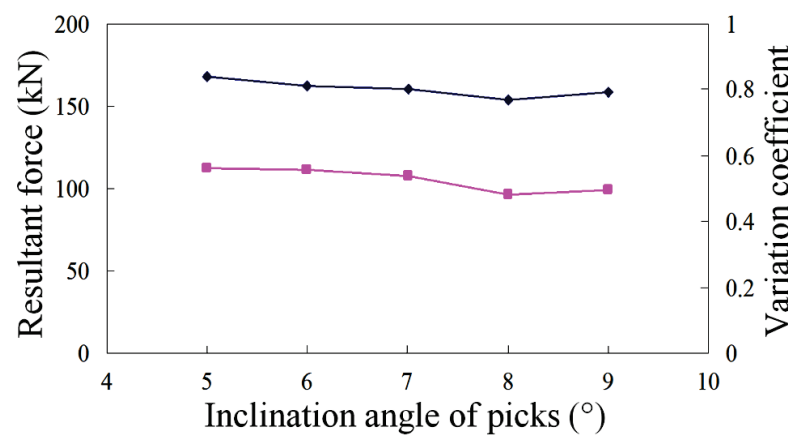

Figure 10 Mean value of resultant force and variation coefficient of cutting load under different inclination angle of picks

From the curves shown in Fig. 10, it can be seen that both the mean value of resultant force and variation coefficient of cutting load decrease slightly along with the increase of inclination angle. For this reason, the proper inclination angle of picks for this cutting head is about $7^{\circ}$ to $9^{\circ}$.

\section{Orthogonal experiment}

In the previous section we have studied the influence of single factor on evaluation index by finite element analysis; however, the effects of these factors on the mean value of resultant force and variation coefficient of cutting load are reciprocal. The effect of these parameters on the evaluation index can be examined by using the orthogonal experimental design.

\subsection{Orthogonal experiment design}

In this study, orthogonal experiment factors are designed for the rotation velocity (factor $A$ ), swing velocity (factor $B$ ), cutting angle of picks (factor $C$ ), and inclination angle of picks (factor $D$ ). According to the previous analysis and design experience, four levels are chosen for each factor, as summarized in Tab. 3.

The proper orthogonal table can be selected as long as the number of factors and the number of levels are decided. Orthogonal array L9 $\left(3^{4}\right)$ is used to arrange the experiments, which indicate that four factors are evaluated and each factor takes three levels with nine experiments altogether, and the scheme of orthogonal experiment is shown in Tab. 4.

Table 3 Factors and levels of orthogonal experiment

\begin{tabular}{|c|c|c|c|c|}
\hline \multirow{4}{*}{ Level } & \multicolumn{4}{|c|}{ Factor } \\
\cline { 2 - 5 } & $\begin{array}{c}A \\
\text { Rotation } \\
\text { velocity } \\
(\mathrm{r} / \mathrm{min})\end{array}$ & $\begin{array}{c}B \\
\text { Swing } \\
\text { velocity } \\
(\mathrm{m} / \mathrm{min})\end{array}$ & $\begin{array}{c}C \\
\text { Cutting } \\
\text { angle } \\
\left({ }^{\circ}\right)\end{array}$ & $\begin{array}{c}D \\
\text { Inclination } \\
\text { angle } \\
\left({ }^{\circ}\right)\end{array}$ \\
\hline 1 & 36 & 1,2 & 47 & 7 \\
\hline 2 & 48 & 1,5 & 48 & 8 \\
\hline 3 & 60 & 1,8 & 49 & 9 \\
\hline
\end{tabular}

Table 4 Scheme of orthogonal experiment

\begin{tabular}{|c|c|c|c|c|}
\hline \multirow{2}{*}{$\begin{array}{c}\text { Experiment } \\
\text { number }\end{array}$} & $\begin{array}{c}A \\
\text { Rotation } \\
\text { velocity } \\
(\mathrm{r} / \mathrm{min})\end{array}$ & $\begin{array}{c}B \\
\text { Swing } \\
\text { velocity } \\
(\mathrm{m} / \mathrm{min})\end{array}$ & $\begin{array}{c}\text { Fater } \\
\text { Cutting } \\
\text { angle } \\
\left({ }^{\circ}\right)\end{array}$ & $\begin{array}{c}\text { F Scheme of orthogonal experiment } \\
\text { Inclination } \\
\text { angle } \\
\left({ }^{\circ}\right)\end{array}$ \\
\hline 1 & 36 & 1,2 & 47 & 7 \\
\hline 2 & 36 & 1,5 & 48 & 8 \\
\hline 3 & 36 & 1,8 & 49 & 9 \\
\hline 4 & 48 & 1,2 & 48 & 9 \\
\hline 5 & 48 & 1,5 & 49 & 7 \\
\hline 6 & 48 & 1,8 & 47 & 8 \\
\hline 7 & 60 & 1,2 & 49 & 8 \\
\hline 8 & 60 & 1,5 & 47 & 9 \\
\hline 9 & 60 & 1,8 & 48 & 7 \\
\hline
\end{tabular}

\subsection{Orthogonal experiment results}

Establish different models with the parameters arranged for the experiments, and take the finite element analysis of different cutting process to get the evaluation index for the orthogonal experimental design. The mean value of resultant force and variation coefficient of cutting load of different experiments are shown in Tab. 5.

The primary and secondary order of each factor can be found through the analysis due to the orthogonal features. Range analysis is used to clarify the significance levels of different influencing factors on the evaluation indexes. The analysis results of the mean value of resultant force and variation coefficient of cutting load are shown in Tab. 6 , with $k_{i 1}, k_{i 2}, k_{i 3}$ corresponding to the mean value of $1,2,3$ level of $i(i=A, B, C, D)$ factors respectively. The variances between each factor are defined as $R$ to analyze the difference between the maximal and minimal value of the three levels for each factor:

$R_{i}=\max \left(k_{i j}\right)-\min \left(k_{i j}\right), \quad j=1,2,3$.

The range analysis of evaluation index data is shown in Tab. 6, which represents the influence degree of various factors on the results. The relationship between the mean value of resultant force and experimental factors is shown in Fig. 11, and the relationship between the variation coefficient of cutting load and experimental factors are shown in Fig. 12. 
Table 5 Evaluation index data obtained by orthogonal experiment

\begin{tabular}{|c|c|c|c|c|c|c|}
\hline \multirow{2}{*}{ Experiment number } & \multicolumn{9}{|c|}{ Factor } & \multicolumn{2}{c|}{ Evaluation index } \\
\cline { 2 - 7 } & $A$ & $B$ & $C$ & $D$ & Resultant force / kN & Variation coefficient \\
\hline 1 & $A 1$ & $B 1$ & $C 1$ & $D 1$ & 163,7 & 0,497 \\
\hline 2 & $A 1$ & $B 2$ & $C 2$ & $D 2$ & 153,5 & 0,481 \\
\hline 3 & $A 1$ & $B 3$ & $C 3$ & $D 3$ & 175,5 & 0,484 \\
\hline 4 & $A 2$ & $B 1$ & $C 2$ & $D 3$ & 132,3 & 0,492 \\
\hline 5 & $A 2$ & $B 2$ & $C 3$ & $D 1$ & 157,2 & 0,535 \\
\hline 6 & $A 2$ & $B 3$ & $C 1$ & $D 2$ & 176,8 & 0,450 \\
\hline 7 & $A 3$ & $\mathrm{~B} 1$ & $\mathrm{C} 3$ & $D 2$ & 133,9 & 0,513 \\
\hline 8 & $A 3$ & $B 2$ & $C 1$ & $D 3$ & 160,8 & 0,491 \\
\hline 9 & $A 3$ & $B 3$ & $C 2$ & $D 1$ & 162,5 & 0,529 \\
\hline
\end{tabular}

Table 6 Range analysis of evaluation index data

\begin{tabular}{|c|c|c|c|c|c|c|c|c|}
\hline \multirow{2}{*}{ Factor } & \multicolumn{4}{|c|}{ Resultant force / kN } & \multicolumn{4}{|c|}{ Variation coefficient } \\
\hline & $A$ & $B$ & $C$ & $D$ & $A$ & $B$ & $C$ & $D$ \\
\hline$k_{i 1}$ & 164,2 & 143,3 & 167,1 & 161,1 & 0,487 & 0,501 & 0,479 & 0,520 \\
\hline$k_{i 2}$ & 155,4 & 157,2 & 149,4 & 154,7 & 0,492 & 0,502 & 0,501 & 0,481 \\
\hline$k_{i 3}$ & 152,4 & 171,6 & 155,5 & 156,2 & 0,511 & 0,488 & 0,511 & 0,489 \\
\hline$R_{i}$ & 11,8 & 28,3 & 17,7 & 6,4 & 0,024 & 0,014 & 0,032 & 0,039 \\
\hline Optimal level & $A 3$ & $B 1$ & $C 2$ & D2 & $A 1$ & $B 3$ & $C 1$ & $D 2$ \\
\hline Primary and secondary order & \multicolumn{4}{|c|}{$B>C>A>D$} & \multicolumn{4}{|c|}{$D>C>A>B$} \\
\hline Optimal combination & \multicolumn{4}{|c|}{$A 3 B 1 C 2 D 2$} & \multicolumn{4}{|c|}{$A 1 B 3 C 1 D 2$} \\
\hline
\end{tabular}

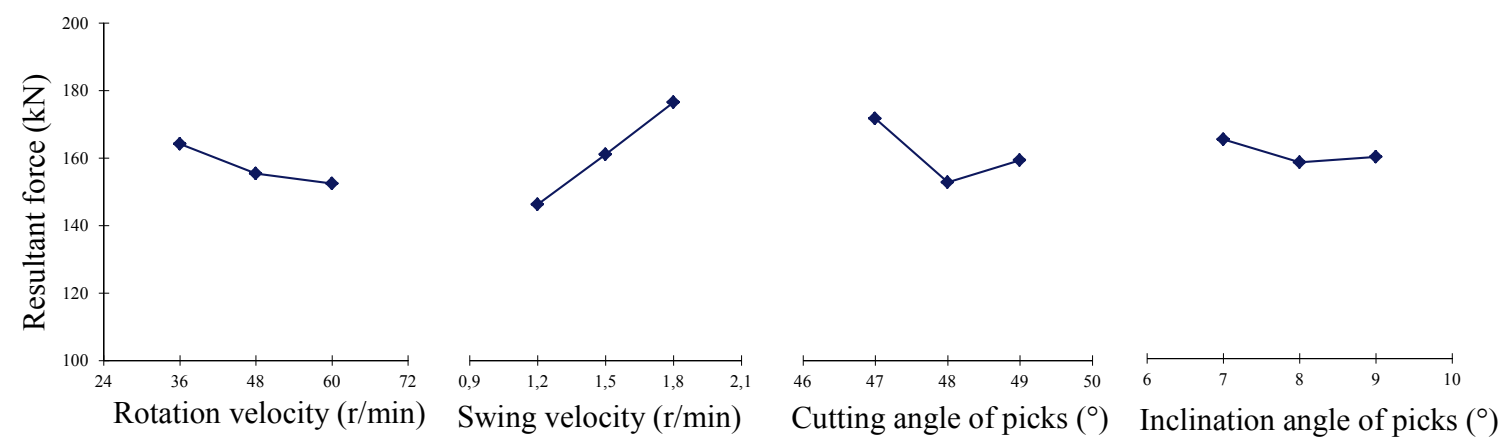

The experimental factors

Figure 11 Relationship between the mean value of resultant force and experimental factors
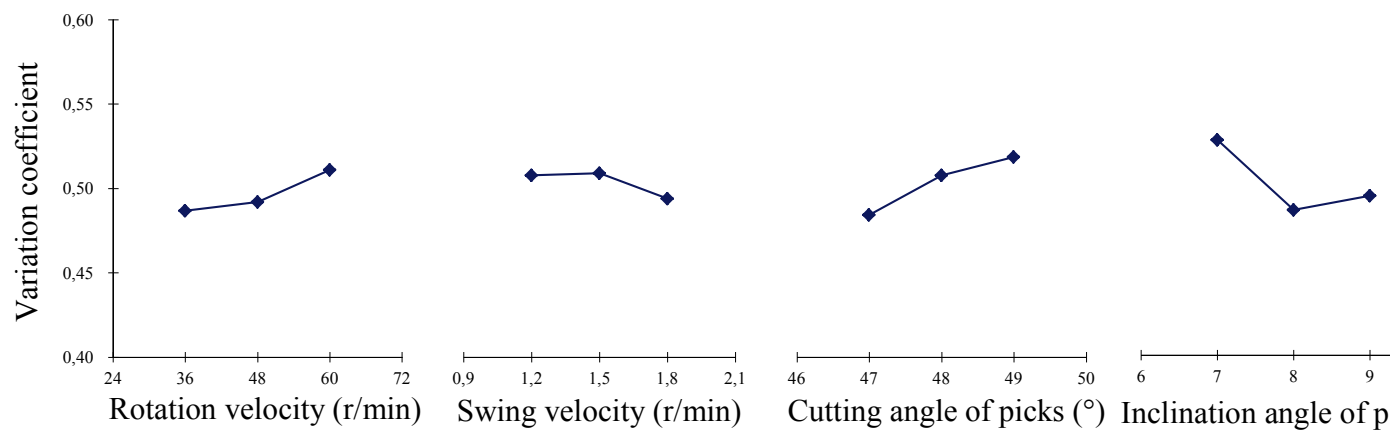

The experimental factors

Figure 12 Relationship between the variation coefficient of cutting load and experimental factors

\subsection{Analysis and discussion of results}

From the results shown in Tab. 6, it can be seen that the factor influence of the mean value of resultant force decreases in the order: $B>C>A>D$ according to the $R$ values, which indicates that the swing velocity is the most important determinant for the mean value of resultant force and the inclination angle has the lowest effect on this evaluation index. For the variation coefficient of cutting load, the biggest influencing factor is inclination angle of picks, followed by cutting angle of picks and rotation velocity; swing velocity has little effect on the variation coefficient of cutting load.

We can see clearly from the relationship shown in Fig. 11 and Fig. 12 the change trend of the mean value of resultant force and the variation coefficient of cutting load with the experimental factors. They do not all agree with the analysis of influence of single factor, which verifies the interaction of these factors on the evaluation index. The change trend of evaluation index with rotation 
velocity and swing velocity is consistent with the influence of single factor, which means that the result caused by these factors is little influenced by other factors. The change trend of evaluation index with cutting angle of picks and inclination angle of picks is inconsistent with the influence of single factor, so we have to consider the change law comprehensively. Accordingly, the best optimization scheme for mean value of resultant force is $A 3 B 1 C 2 D 2$ and the best optimization scheme for variation coefficient of cutting load is $A 1 B 3 C 1 D 2$.

In this study, the main evaluation index is the mean value of resultant force which determines the fatigue life of cutting picks and cutting head; and the range for variation coefficient of cutting load of different optimization scheme is small which indicates that this evaluation index is less affected by the factors analyzed in the paper. So the optimal road header cutting head design is adopted as $A 3 B 1 C 2 D 2$ (i.e. rotation velocity is $60 \mathrm{r} / \mathrm{min}$, swing velocity is $1,2 \mathrm{~m} / \mathrm{min}$, cutting angle of picks is $48^{\circ}$, and inclination angle of picks is $8^{\circ}$ ) based on the results of the orthogonal experiment. The evaluation indexes for optimal design can also be calculated by finite element analysis; the mean value of resultant force is about 124,3 $\mathrm{kN}$ and the variation coefficient of cutting load is 0,466 . Compared with the original design, the two evaluation indexes decreased by 18,3\% and 5,5\% separately.

\section{Conclusion}

In order to improve the cutting performance of the roadheader cutting head, an orthogonal experiment is carried out to optimize the parameters. For this purpose, the rotation velocity, the swing velocity, the cutting angles of picks, and the inclination angles of picks are chosen as the variable for the optimization, and the mean value of resultant force and variation coefficient of cutting load are chosen as optimization objective. The effects of these parameters on evaluation indexes are investigated by finite element analysis. The following conclusions can be drawn from the results obtained in this study.

1. The mean value of resultant force decreases along with the increase of rotation velocity and increases along with the increase of swing velocity.

2. The change trend of the mean value of resultant force and the variation coefficient of cutting load with the experimental factors by orthogonal experiment do not all agree with the analysis of influence of single factor, which verifies the interaction of these factors on the evaluation index.

3. The optimal roadheader cutting head design for this study is rotation velocity as $60 \mathrm{r} / \mathrm{min}$, swing velocity as $1,2 \mathrm{~m} / \mathrm{min}$, cutting angle of picks as $48^{\circ}$, and inclination angle of picks as $8^{\circ}$, which decrease the mean value of resultant force and variation coefficient of cutting load by $18,3 \%$ and $5,5 \%$ separately compared with the original design.

\section{Acknowledgements}

This work was supported by the National Natural Science Foundation of China (Grant No. 51375282 and 51305223), the Program for Changjiang Scholars and Innovative Research Team in University (Grant no.
IRT1266), the Special funds for cultivation of Taishan Scholars, the Shandong Provincial Natural Science Foundation of China (No. ZR2015EM017) and the Innovation Foundation for Graduate Students of Shandong University of Science \& Technology (Grant No. YC150211). The authors express sincere thanks to the reviewers for their helpful comments and suggestions for improving this paper.

\section{References}

[1] Li, X. Y.; Huang, B. B.; Li, C. C. et al. Dynamics analysis on roadheader cutting head based on LS-DYNA. // Journal of Convergence Information Technology. 7, 23(2012), pp. 333-340. DOI: 10.4156/jcit.vol7.issue23.39

[2] Hekimoglu, O. Z.; Ozdemir, L. Effect of Angle of Wrap on Cutting Performance of Drum Shearers and Continuous Miners. // Mining Technology. 113, 2(2004), pp. 118-122. DOI: $10.1179 / 037178404225004977$

[3] Bilgin, N.; Dincer, T.; Copur, H. et al. Some geological and geotechnical factors affecting the performance of a roadheader in an inclined tunnel. // Tunneling and Underground Space Technology. 19, 6(2004), pp. 629-636. DOI: 10.1016/j.tust.2004.04.004

[4] Khair, A. W. Research and innovations for continuous miner's cutting head, for efficient cutting process of rock/coal. $/ / 17^{\text {th }}$ International Mining Congress and Exhibition of Turkey, 2001, pp. 45-55.

[5] Sun, Y.; Li, X. S. Influence of cutting interactions on cutting force of a pick. // AASRI Procedia. 3, (2012), pp. 694-699. DOI: 10.1016/j.aasri.2012.11.110

[6] Zhang, Q. Q.; Han, Z. N.; Liu, W. H. Comparison and analysis of cutting performance of longitudinal cutting heads with various numbers of helical lines. // Mining Machinery. 41, 5(2013), pp. 12-16 (in Chinese)

[7] Guo, Y. F.; Zhang, Y. Z.; Liu, D. S. et al. Kinematics analysis and computer simulation on longitudinal cutting head of roadheader. // Journal of China Coal Society. 27, 2(2002), pp. 68-72.

[8] Zhang, M. Q. Study on cutting head moving speed of mine roadheader determined based on pick tracing. // Coal Science and Technology. 40, 8(2012), pp. 71-74.

[9] Zhang, M. Q. Analysis method of translational speed to rotate speed for cutting head by pick trajectory. // Coal Mine Machinery. 33, 11(2012), pp. 62-64.

[10] Rostami, J.; Ozdemir, L.; Neil， D. M. Roadheaders performance optimization for mining and civil construction // Proceeding of $13^{\text {th }}$ Annual Technical Conference, Institute of Shaft Drilling Technology (ISDT), 1994, pp. $18-21$.

[11] Zhang, Q.; Mao, J.; Tian, D. F. Multi-objective optimization fuzzy reliability design for cutting head of roadheader based on genetic algorithm. // Journal of China Coal Society. 33, 12(2008), pp. 1435-1437.

[12] Liu, G.; Mu, D. S.; Duan, S. X. et al. Design parameters optimization of cutting head of cantilever roadheader based on genetic algorithm. // Applied Mechanics and Materials. 215, (2012), pp. 193-196. DOI: 10.4028/www.scientific.net/amm.215-216.193

[13] Zhang, Q.; Li. S. J.; Tian, Y. Multi-objective incomplete probability information optimization reliability design based on ant colony algorithm. // Journal of Software Engineering and Applications. 2, 5(2009), pp. 350-353. DOI: $10.4236 /$ jsea.2009.25046

[14] Zhang, X.; Li, X. P. Optimized design of kinematics parameters of cutting head for roadheaders. // Colliery Mechanical and Electrical Technology. 5, (2004), pp. 3033. 
[15] Zhang, X.; Zeng, Q. L. The study of multi-objective optimization design for cutting head of roadheader. // Coal Mine Machinery. 6, 1(2005), pp. 1-3.

[16] Zhang, X.; Liu, X. Z.; Zhang, J. W. et al. Multi-objective optimization design for cutting head of roadheader. // Key Engineering Materials. 450, (2011), pp. 75-78. DOI: 10.4028/www.scientific.net/KEM.450.75

[17] Peng, T. H. Optimization to the motion parameter of the cutting head of the transverse tunneler and the simulation analysis to the load. // Mining \& Processing Equipment. 34, 9(2006), pp. 19-22.

[18] Sha, Y. D.; Li, X. H. Fuzzy optimization model for structural parameters of longitudinal cutting head of roadheader. // Journal of Liaoning Technical University (Natural Science Edition). 25, (2006), pp. 231-233.

[19] Su, O.; Ali Akcin, N. Numerical simulation of rock cutting using the discrete element method. // International Journal of Rock Mechanics and Mining Sciences. 48, 3(2011), pp. 434-442. DOI: 10.1016/j.jirmms.2010.08.012

[20] Wan, L.; Wang, D. Z.; Gao, Y. Y. Investigations on the Effects of Different Tool Edge Geometries in the Finite Element Simulation of Machining. // Strojniski vestnikJournal of Mechanical Engineering. 61, 3(2015), pp. 157166. DOI: $10.5545 /$ sv-jme.2014.2051

[21] Yanda H.; Ghani J. A.; Rizal M.; Che Haron C. H. Performance of Uncoated and Coated Carbide Tools in Turning FCD700 Using FEM Simulation. // International Journal of Simulation Modelling. 14, 3(2015), pp. 416-425. DOI: $10.2507 / I J S I M M 14(3) 4.286$

[22] Ooi, J. B.; Wang, X.; Lim, Y. P.; Tan, C.; Ho, J. H.; Wong, K. C. Parametric Optimization of the Output Shaft of a Portal Axle using Finite Element Analysis. // Strojniski vestnik-Journal of Mechanical Engineering. 59, 10(2013), pp. 613-619. DOI: 10.5545/sv-jme.2012.887

[23] Ji, Y.; Yin, H.; Wang, P. FEA of roadheader picks based on LS-DYNA. // Mining \& Processing Equipment. 39, 2(2011), pp. 33-36.

[24] Ma, G. Y.; Huang, B. B. Optimization of process parameters of stamping forming of the automotive lower floor board // Journal of Applied Mathematics. http://www.hindawi.com/journals/jam/2014/470320/.

[25] Zhou, L.; Shi, W.; Wu, S. Performance optimization in a centrifugal pump impeller by orthogonal experiment and numerical simulation. // Advances in Mechanical Engineering. http://www.hindawi.com/journals/ame/ 2013/385809/.

[26] Mallick, Z. Optimization of operating parameters for a back-pack type grass trimmer. // International Journal of Industrial Ergonomics. 38, 1(2008), pp. 101-110. DOI: 10.1016/j.ergon.2007.09.005

[27] Sekulic, M.; Kovac, P.; Gostimirovic, M.; Kramar, D. Optimization of high-pressure jet assisted turning process by Taguchi method. // Advances in Production Engineering \& Management. 8, 1(2013), pp. 5-12. DOl: 10.14743/apem2013.1.148

[28] Vijay Sekar K. S.; Pradeep Kumar M. Optimising Flow Stress Input for Machining Simulations Using Taguchi Methodology. // International Journal of Simulation Modelling. 11, 1(2012), pp. 17-28. DOI: 10.2507/IJSIMM11(1)2.195

[29] Satheesh, M.; Edwin Raja Dhas, J. Hybrid Taguchi method for optimizing flux cored arc weld parameters for mild steel. // Advances in Production Engineering \& Management. 9, 2(2014), pp. 95-103. DOI: 10.14743/apem2014.2.179

[30] Evans, I. A theory of the cutting force for point attack picks. // International Journal of Mining Engineering. 2, 1(1984), pp. $63-71$. DOI: $10.1007 / \mathrm{BF} 00880858$
[31] Bilgin, N.; Demircin, M. A.; Copur, H. Dominant rock properties affecting the performance of conical picks and the comparison of some experimental and theoretical results. // International Journal of Rock Mechanics and Mining Sciences. 43, 1(2006), pp. 139-156. DOI: 10.1016/j.jijmms.2005.04.009

[32] Li, X. H. The Key Technology Research of the Roadheader Cutting. Mechanical Industry Press, China, 2008.

[33] Xu, X. Y. Inspection of cutting bit installation parameters for cutting head of mine road header. // Coal Science and Technology. 33, 5(2005), pp. 59-61.

\section{Authors' addresses}

Xueyi Li, Assoc. Prof. Dr.

College of Mechanical and Electronic Engineering,

Shandong University of Science and Technology,

266590 Qingdao, China

E-mail: lixueyi07@tsinghua.org.cn

\section{Yonggang Lv, master graduate student}

College of Mechanical and Electronic Engineering, Shandong University of Science and Technology, 266590 Qingdao, China

E-mail: Yongganglv406@163.com

\section{Shucai $\mathrm{Xu}, \mathrm{Dr}$.}

State Key Laboratory of Automotive Safety and Energy, Department of Automotive Engineering, Tsinghua University, 100084 Beijing, China

E-mail: xushe@tsinghua.edu.cn

Qingliang Zeng, Prof. Dr.

College of Mechanical and Electronic Engineering Shandong University of Science and Technology, 266590 Qingdao, China

E-mail: qlzeng@163.com

\section{Binbing Huang}

Suzhou Automobile Research Institute, Tsinghua University, 215134 Suzhou, China

E-mail: kinghuang1990@163.com 